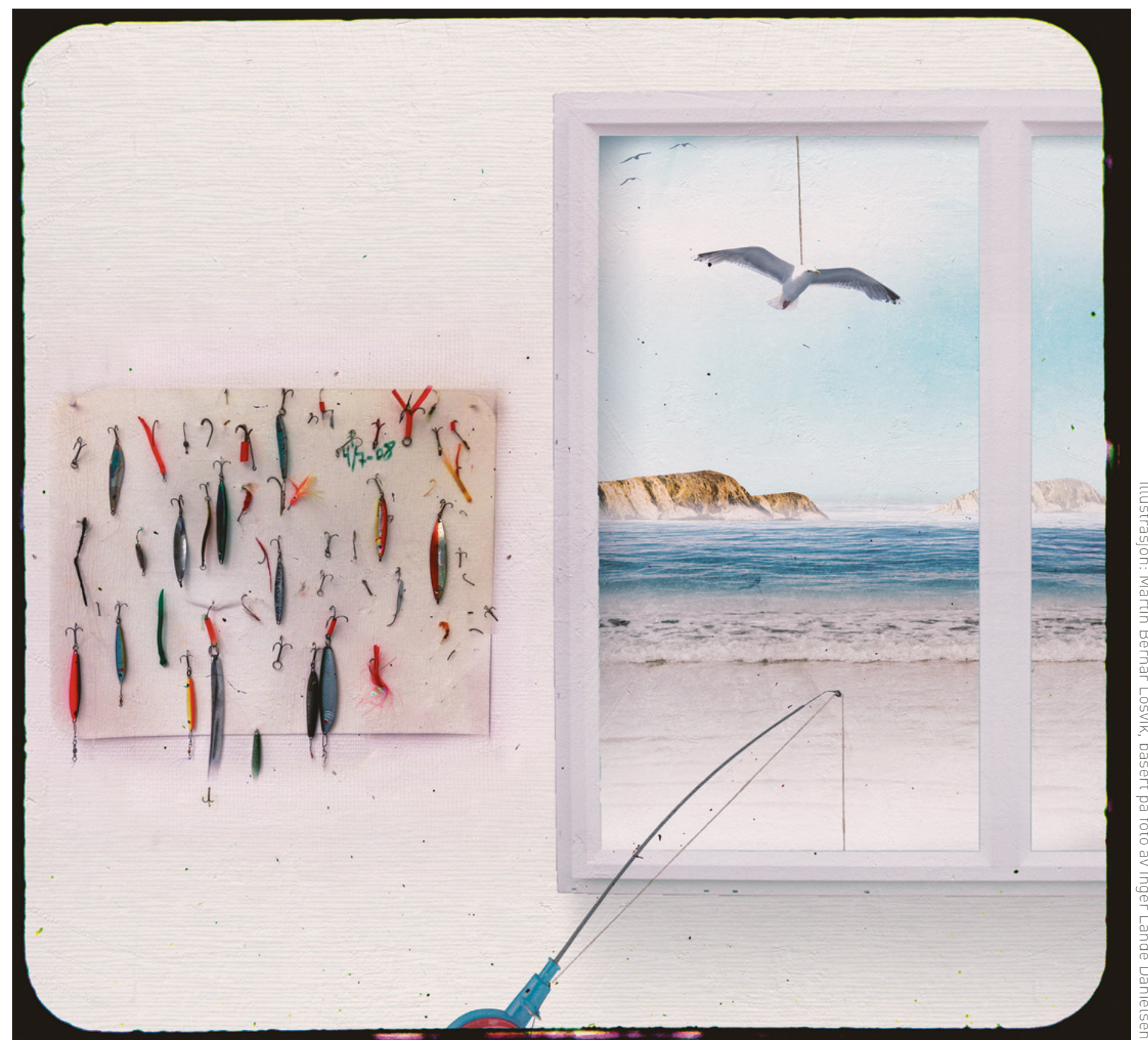

\title{
Øygarden legesenter
}

(i)

Ute i havgapet mot Nordsjøen i Hordaland ligger øykommunen med det passende navnet Øygarden. Kommunen består av ni store øyer og et drøss med små. I Øygarden har det bodd folk i all sin tid.

De eldste funnene etter mennesker i Norge er blitt gjort i denne kommunen. Nå bor det 4733 innbyggere på øyene som kan benytte kommunens fire fastleger. De holder til på Øygarden legesenter. 